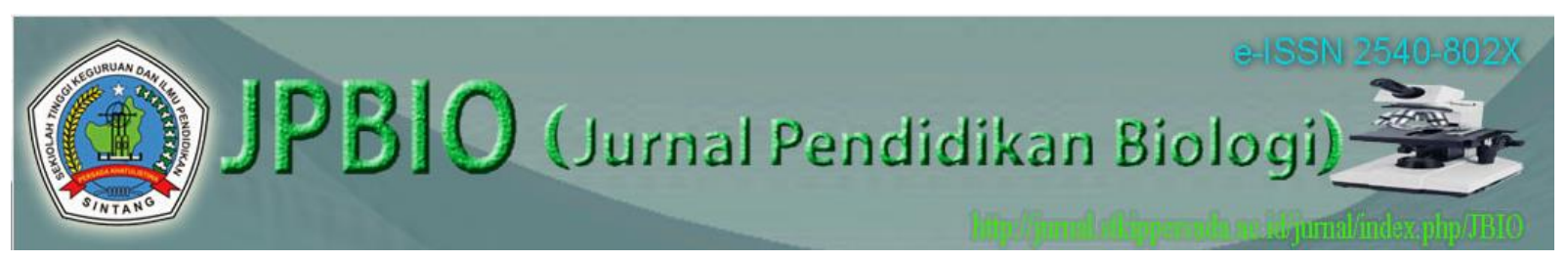

JPBIO (Jurnal Pendidikan Biologi)

Vol. 2 No. 2 November 2017 | $20-26$

ISSN 2540-802x (Online)

DOI: http://dx.doi.org/10.31932/ JPBIO (Jurnal Pendidikan Biologi)

http://jurnal.stkippersada.ac.id/jurnal/index.php/JBIO

\title{
PENERAPAN METODE STUDENT FACILITATOR AND EXPLAINING BERBANTUAN MEDIA PETA TIMBUL TERHADAP KEMAMPUAN BERPIKIR KRITIS SISWA PADA MATERI SEL
}

\author{
Veroneka heni ${ }^{1}$, Hilarius Jago Duda ${ }^{2^{*}}$, Markus lyus Supiandi ${ }^{3}$ \\ ${ }^{1}$ Mahasiswa Program Studi Pendidikan Biologi, STKIP Persada Khatulistiwa Sintang \\ 2,3Dosen Program Studi Pendidikan Biologi, STKIP Persada Khatulistiwa Sintang \\ E-mail: veronekaheni07@gmail.com,hilariusjagod@yahoo.com*, \\ msupiandi@gmail.com
}

Diterima: 15 Mei 2017

Direvisi: 10 Juni 2017

Disetujui: 22 Oktober 2017

\begin{abstract}
ABSTRAK
Penelitian ini dilatar belakangi oleh aktivitas siswa dalam proses pembelajaran masih kurang aktif, takut, dan malu untuk menggemukakan pendapatnya sendiri sehingga berpengaruh terhadap kemampuan berpikir kritis siswa. Tujuan penelitian ini adalah untuk mengetahui penerapan metode student facilitator and explaining berbantuan media peta timbul terhadap kemampuan berpikir kritis siswa pada materi sel. Variabel bebas dalam penelitian ini yaitu "metode student facilitator and explaining berbantuan media peta timbul" sedangkan variabel terikat yaitu "kemampuan berpikir kritis siswa". Pendekatan yang digunakan adalah kuantitatif, dengan metode eksperimen dan bentuk Quasi Experiment. Desain penelitian ini menggunakan Nonequivalent Control Group Design. Populasi dalam penelittian ini adalah yang berjumlah 73 siswa. Teknik pengumpulan dan alat pengumpulan data yang digunakan adalah teknik observasi langsung (lembar observasi), teknik pengukuran (lembar tes), dan komunikasi tidak langsung (lembar angket). Setelah dianalisis diketahui bahwa penerapan metode student facilitator and explaining berbantuan media peta timbul mendapat perbedaan yang signifikan terhadap kemampuan berpikir kritis siswa. Hal ini ditunjukan dengan pengujian hipotesis pada hasil posttest yang memperoleh nilai $Z_{\text {hitung }} 30,33$ dan nilai $Z_{\text {tabel }}$ pada taraf signifikan 0,01 sebesar 0,4949 . Hal ini berarti nilai $Z_{\text {hitung }}>Z_{\text {tabel }}$ yaitu $30,33>0$, 4949 maka Ha diterima yang artinya terdapat perbedaan yang signifikan kemampuan berpikir kritis siswa pada materi sel antara kelas eksperimen dan kelas kontrol.
\end{abstract}

Kata Kunci: student facilitator and explaining, media peta timbul, kemampuan berpikir kritis

\begin{abstract}
This research is motivated by the activity of the student in the learning process which is stll lack, fear, and shy to express their own opinion so that affect the students' critical thinking skills. The purpose of this study was to determine the implementation of student facilitator and explaining method with relief map assisted to students' critical thinking skills on cell material. The free variable in this study was "student facilitator and explaining method with relief map assisted" while the bound variable was "students' critical thinking skills". This
\end{abstract}


research was quantitative in nature with experimental methods in form of Quasi Experiment. The study design used was nonequivalent control group design. The population of this research was the students grade XI IPA of SMA Panca Setya Sintang in the academic year of 2016/2017 totaling 73 stdents. Furthermore, the technique and the instrument of the data collecting used were direct observation (observation sheets), measurement technique (test sheets), and indirect communication (questionnaires). After analyzing the data, it was found that the student facilitator and explaining assisted by relief map showed the significant differences to the student's criticall thinking ability. It was proved by the result of the hypothesis test, the result of the posttest obtained the value of $z_{\text {count }}$ was 30,33 and the value of $Z_{\text {table }}$ was at the significant level 0,01 as 0,4949 . It means that the value of $Z_{\text {count }}>Z_{\text {zable }}$ or 30,33>0,4949 so Ha accepted which means that there was a significant difference of the students' critical thinking skills cell material between the experimental class and control class.

Keywords: student facilitator and explaining, relief map media, critical thinking skills

\section{PENDAHULUAN}

Berhasil atau tidaknya suatu proses pendidikan sangat dipengaruhi oleh pembelajaran yang berlangsung. Menurut Suprijono (2009: 13) mengungkapkan bahwa, "Pembelajaran berdasarkan makna leksikal berarti proses, cara dan perbuatan mempelajari". Oleh karena itu, pembelajaran hendaknya dirancang sedemikian rupa sehingga siswa tidak merasa tertekan atau terpaksa, dapat menjadikan siswa aktif baik secara fisik maupun mental, menarik perhatian dan minat belajar sehingga siswa dapat memusatkan perhatiannya secara penuh pada proses pembelajaran.

Berdasarkan pra observasi yang dilakukan peneliti dengan guru biologi yang mengajar di kelas XI IPA Sekolah Menengah Atas Panca Setya Sintang pada hari Senin tanggal 02 April 2016 pukul: 10:30 WIB diketahui hasil belajar biologi siswa dari ujian akhir semester ganjil tahun pelajaran 2015/2016, di kelas XI IPA 1 siswa yang mencapai KKM sebanyak 12 orang dan siswa yang belum mencapai KKM sebanyak 28 orang dari 36 siswa, sedangkan di kelas XI IPA 2 siswa yang mencapai KKM sebanyak 26 orang dan yang belum mencapai KKM sebanyak 10 orang dari 36 siswa. Dari persentase tersebut tampak bahwa rata-ratanilai siswa masih rendah atau di bawah KKM (kriteria ketuntasan minimal) yang ditentukan yaitu 75. Menurut guru bidang studi mata pelajaran biologi kelas XI IPA SMA Panca Setya Sintang, pembelajaran yang berlangsung kurang variatif karena didominasi oleh guru, siswa masih pasif, bosan dan jenuh disebabkan bahasa-bahasa ilmiah dalam materi, guru menggunakan metode yang biasa digunakan di sekolah tersebut karena mudah untuk diterapkan serta tidak memerlukan alat-alat dan bahan praktik.

Selain itu berdasarkan informasi yang diperoleh dari beberapa siswa kelas XI IPA SMA Panca Setya Sintang bahwa siswa kurang percaya diri untuk menyampaikan pendapat dan masih takut untuk berbicara di depan teman-teman sekelas, secara garis besar siswa kurang memahami pelajaran yang diajarkan guru disebabkan metode yang biasa digunakan di sekolah tidak menarik minat belajar, siswa menjadi bosan dalam belajar, guru merasa mudah dalam menerapkan metode yang biasa digunakan selama belajar, pembelajaran kurang melibatkan siswa untuk berpikir secara kritis dalam membentuk pengetahuan siswa. Kemampuan siswa dalam mengolah dan memproses informasi kurang dikembangkan.

Menyikapi masalah lemahnya kemampuan berpikir kritis siswa perlu mendapat perhatian dan solusi yang tepat. "berpikir kritis adalah interpretasi dan evaluasi yang terampil dan aktif terhadap observasi dan komunikasi, informasi, dan argumentasi Fisher, (2008: 10). Salah satu materi biologi yang sangat sulit dipandang tepat dikembangkan dengan kemampuan berpikir kritis siswa dalam materi sel. Materi sel dipilih karena sel merupakan konsep dasar suatu makhluk hidup yang perlu dipahami dengan baik oleh siswa sebelum mempelajari banyak konsep biologi lainnya. Mengingat daya pikir kritis dan pemahaman siswa masih kurang dalam materi ini maka memerlukan suatu metode pembelajaran yang tepat dan efektif untuk diterapkan sebagai upaya untuk meningkatkan kemampuan berpikir kritis siswa. 
Metode pembelajaran yang digunakan guru masih didominasi oleh metode ceramah atau pembelajaran yang biasanya digunakan di sekolah pada setiap penyampaian materi. Menurut Trianto,(2009: 6) "Proses pembelajaran yang terjadi di dalam kelas hanya berlangsung satu arah (one way system) yaitu hanya menekankan pada penyampaian informasi yang disampaikan guru kepada siswa, sedangkan siswa hanya menerima informasi yang diberikan oleh guru".

Akibatnya proses pembelajaran dirasakan sebagai sesuatu yang membosankan bagi siswa karena banyaknya konsep-konsep dalam mata pelajaran biologi yang harus mereka hafalkan tentunya sangat membebani proses berpikir. Proses pembelajaran yang biasa digunakan belum memberikan kebebasan kepada siswa untuk belajar aktif dalam mengkontruksi pemikirannya sehingga kemampuan siswa untuk penguasaan konsep dan pemecahan masalah pun masih rendah sehingga berdampak pada hasil belajar siswa yang cenderung rendah. Untuk meningkatkan kemampuan berpikir kritis siswa pada materi biologi khususnya pada materi sel maka perlu adanya upaya penyempurnaan proses belajar, salah satu metode pembelajaran yang peneliti direkomendasikan untuk mengatasi permasalahan di atas adalah metode pembelajaran student facilitator and explaining.

Metode pembelajaran student facilitator and explaning merupakan salah satu metode pembelajaran Aktif, Inovatif, Kreatif, Efektif dan Menyenangkan atau disebut PAIKEM. Suprijono, (2009: 111) PAIKEM adalah pembelajaran bermakna yang dikembangkan dengan cara membantu siswa untuk membangun keterkaitan antara informasi (pengetahuan) baru dengan pengalaman yang telah dimiliki dan dikuasai siswa. Selanjutnya, siswa diajarkan tentang konsep dan bagaimana konsep tersebut dapat dipergunakan di luar kelas. Siswa diperkenankan bekerjasama secara kooperatif.Student facilitator and explaning termasuk dalam kategori metode pembelajaran aktif. Taniredja (2013: 110)Student facilitator and explainingadalah metode pebelajaran di mana siswa/peserta mepresentasikan ide/pendapat pada rekan peserta lainnya.

Metode pembelajaran student facilitator and explaning diterapkan pada materi sel didasari beberapa pertimbangan yaitu karena kemampuan berpikir kritis yang terlihat dari hasil belajar siswa di Sekolah Menengah Atas Panca Setya Sintang tahun pelajaran 2015/2016 masih rendah terlihat dari nilai ulangan dan nilai evaluasi harian, banyak konsep dalam materi ini yang harus dipahami dan dikuasai jadi tidak hanya hapal secara verbal, metode yang digunakan guru belum bervariasi, dan materi sel belum pernah diajarkan dengan metode ini.

Menurut Lia, (2015)"Rata-rata nilai hasil belajar Biologi siswa pada kelompok eksperimen yang belajar dengan model pembelajaran Student Facilitator and Explaining berbantuan media peta konsep lebih tinggi dari kelompok kontrol yang belajar secara konvensional yaitu 0,61>0,41". Dari hasil penelitian ini terbukti bahwa "penerapan metode pembelajaran student facilitator and explaining memberikan hasil yang lebih baik terhadap penguasaan konsep siswa pada materi keanekaragaman hayati kelas X Sekolah Menengah Atas Nusantara Indah Sintang tahun pelajaran 2014/2015". Berdasarkan latar belakang tersebut, peneliti tertarik untuk melakukan penelitian dengan judul:"Penerapan metode student facilitator and explaining berbantuan media peta timbul terhadap kemampuan berpikir kritis siswa pada materi sel kelas XI IPA Sekolah Menengah Atas Panca Setya Sintang.

\section{METODE PENELITIAN}

Pendekatan penelitian yang digunakan dalam penelitian ini adalah pendekatan penelitian kuantitatif. Metode penelitiannya yaitu metode eksperimen dengan bentuk Quasi Experimental. Menurut Sugiyono (2013: 2) "metode penelitian pada dasarnya merupakan cara ilmiah untuk mendapatkan data dengan tujuan dan kegunaan tertentu, terdapat empat kata kunci yang perlu diperhatikan, yaitu cara ilmiah, data, tujuan, dan kegunaan".

Metode kuantitatif digunakan untuk menguji penerapan metode student facilitator and explaining berbantuan media peta timbul terhadap kemampuan berpikir kritis siswa kelas XI IPA SMA Panca Setya Sintang. Hasil data dalam penelitian yang diperoleh dalam bentuk angka dan dijabarkan dalam bentuk kata. Desain penelitian yang digunakan adalah Nonequivalent Control Group Design. 
Pengambilan sampel dilakukan dengan teknik purposive sampling. Penelitian ini dilaksanakan di SMA Panca Setya Sintang semester ganjil 2016/2017.Populasi penelitian ini adalah seluruh siswa kelas XI IPA 1 berjumlah 36 sebagai kelas eksperimen dan XI IPA 2 berjumlah 37 sebagai kelas kontrol.Variabel bebas yaitu metode student facilitator and explaining berbantuan media peta timbul, dan variabel terikat yaitu kemampuan berpikir kritis. Pengumpulan data menggunakan beberapa instrumen yaitu: lembar observasi, soal tes, dan angket. Analisis data pada soal tes meliputi uji normalitas, uji homogenitas, dan uji hipotesis dengan uji z-2 sampel.

\section{HASIL PENELITIAN}

Berdasarkan analisis hasil pretest dan posttest di kelas eksperimen dan kelas kontrol terhadap kemampuan berpikir kritis siswa pada materi sel maka dapat dilihat pada Tabel 1 .

Tabel 1.Nilai Pretest dan Posttest Siswa Kelas XI IPA SMA Panca Setya Sintang

\begin{tabular}{rcccc} 
& \multicolumn{2}{c}{ Kelas Eksperimen } & \multicolumn{2}{c}{ Kelas Kontrol } \\
\cline { 2 - 5 } Nilai & Pretest & Posttest & Pretest & Posttest \\
\hline Nilai Tertinggi & 80 & 100 & 73 & 98 \\
\hline Nilai Terendah & 25 & 75 & 15 & 75 \\
\hline Nilai Rata-rata & 47 & 87,41 & 46,64 & 85,59 \\
\hline
\end{tabular}

Kemampuan berpikir kritis siswa dianalisis dengan cara mengubah skor menjadi nilai. Nilai belajar siswa diperoleh dari skor yang dicapai dibagi skor total kemudian dikali seratus. Hasil analisis data pretest dan posttest dari setiap indikator kemampuan berpikir kritis pada kelas eksperimen dan kontrol dapat dilihat pada Tabel 2.

Tabel 2. Hasil Pretest dan Posttest Siswa Setiap Indikator Kemampuan Berpikir Kritis (\%)

\begin{tabular}{lllll}
\hline \multirow{2}{*}{\multicolumn{1}{c}{ Indikator }} & \multicolumn{2}{c}{ Kelas Eksperimen } & \multicolumn{2}{c}{ Kelas Kontrol } \\
\cline { 2 - 5 } & Pretest & posttest & pretest & Posttest \\
\hline Interpretasi menarik kesimpulan & 97,22 & 100 & 91,17 & 100 \\
\hline Konsep & 83,33 & 100 & 88,22 & 100 \\
\hline Asumsi & 94,44 & 100 & 85,29 & 100 \\
\hline Konsep & 83.33 & 100 & 85,29 & 100 \\
\hline Pertanyaan terhadap masalah & 100 & 100 & 91,17 & 100 \\
\hline
\end{tabular}

Berdasarkan hasil analisis pretest dan posttest setiap indikator kemampuan berpikir kritis pada kelas eksperimen dan kelas kontrol terlihat bahwa indikator konsep memiliki nilai terendah diantara kelima indikator kemampuan berpikir kritis dengan persentase pretest 83,33\% dikelas eksperimen sedangkan presentase pretest di kelas kontrol 88,22\% dan $85,29 \%$. Hal ini dikarenakan siswa belum diberikan konsep mengenai materi sel, setelah di berikan perlakuan dengan materi yang sama di kelas eksperimen dan kelas kontrol maka presentase hasil posttest $100 \%$ siswa menjawab semua soal. Adapun hasil peningkatan setiap indikator berpikir kritis dapat dilihat pada Tabel 3.

Tabel 3. Hasil Peningkatan Pretest dan Posttest Siswa Setiap Indikator Berpikir Kritis

\section{Kelas Eksperimen Kelas Kontrol}

\begin{tabular}{lcccccc}
\cline { 2 - 6 } \multicolumn{1}{c}{ Indikator } & Pretest & Posttest & $\begin{array}{c}\text { Indek } \\
\text { Gain }\end{array}$ & Pretest & Posttest & $\begin{array}{c}\text { Indek } \\
\text { Gain }\end{array}$ \\
\hline $\begin{array}{l}\text { Interpretasi dan menarik } \\
\text { kesimpulan }\end{array}$ & 1,83 & 3,44 & 87.97 & 1,70 & 2,97 & 74,70 \\
\hline Konsep & 2,63 & 5,13 & 95,05 & 2,35 & 4,29 & 82,55 \\
\hline Asumsi & 1,77 & 5,13 & 189,83 & 1,73 & 4,45 & 157,22 \\
\hline Konsep & 4,22 & 5,27 & 24,88 & 4,08 & 4,86 & 19,11 \\
\hline $\begin{array}{l}\text { Pertanyaan terhadap } \\
\text { masalah }\end{array}$ & 2,30 & 14,13 & 514,34 & 2,52 & 13,40 & 431,74 \\
\hline
\end{tabular}


Berdasarkan hasil peningkatan setiap indikator maka disimpulkan bahwa setiap indikator di kelas eksperimen lebih tinggi dibanding kelas kontrol. Hasil analisis datapretest siswa kelas eksperimen adalah tertinggi 80 , nilaiterendah 25 , rata-rata 47 . Pada posttestnilai tertinggi 100 , nilai terendah 75 , rata-rata 87,41 . Pada kelas kontrol diperoleh nilai pretest dengan nilai tertinggi 73 , nilai terendah 15 , rata-rata 46,64. Pada posttest diperoleh nilai tertinggi 98, nilai terendah 75, rata-rata 85,59.Berdasarkan perhitungan hasil Indeks Gain, dapat ditarik kesimpulan bahwa kemampuan berpikir kritis siswa pada materi sel meningkat dengan kategori "tinggi" setelah diterapkan metode student facilitator and explaining berbantuan media peta timbul. Adapun perbandingan N-Gain antara kelas eksperimen dan kelas kontrol dapat dilihat pada Tabel 4.

Tabel 4. Peningkatan Kemampuan Berpikir Kritis

\begin{tabular}{cccc}
\hline Kelas & $\mathbf{n}$ & $\mathbf{N}-$ Gain & Kategori \\
\hline Eksperimen & 36 & 0,76 & Tinggi \\
\hline Kontrol & 37 & 0,72 & Tinggi \\
\hline
\end{tabular}

Berdasarkan hasil perhitungan statistik untuk kemampuan berpikir kritis siswa menunjukkan bahwa taraf kepercayaan $\alpha=1 \%, x^{2}$ hitung $<$ dari $x^{2}$ tabel yaitu data pretest kelas XI IPA 1 sebagai kelas eksperimen 10,26 < 13,3, pretest kelas XI IPA 2 sebagai kelas kontrol 11,26 < 13,3, posttest kelas XI IPA 1 sebagai kelas eksperimen 8,28 < 13,3, posttest kelas XI IPA 2 sebagai kelas kontrol 10,18 < 13,3 maka dapat dinyatakan bahwa sebaran data kelas XI IPA 1 dan XI IPA 2 dalam penelitian ini berdistribusi normal. Untuk lebih jelasnya, hasil uji normalitas dapat dilihat pada Tabel 5.

Tabel 5. Hasil Uji Normalitas Data Pretest dan posttest Kelas Eksperimen dan Kelas Kontrol

\begin{tabular}{cccccc}
\hline Data yang diuji & $\overline{\boldsymbol{X}}$ & $\mathbf{X}^{2}$ hitung & $\mathbf{X}^{2}$ tabel & Alpha & Keterangan \\
\hline Pretest Eksperimen & 47 & 10,26 & 13,3 & $1 \%$ & Normal \\
\hline Pretest Kontrol & 46,64 & 11,26 & 13,3 & $1 \%$ & Normal \\
\hline Posttest Eksperimen & 87,41 & 8,28 & 13,3 & $1 \%$ & Normal \\
\hline Posttest Kontrol & 85,59 & 10,18 & 13,3 & $1 \%$ & Normal \\
\hline
\end{tabular}

Berdasarkan hasil perhitungan hipotesis pretest kelas ekperimen dan kelas kontrol diketahui bahwa nilai $Z_{\text {hitung }}$ adalah -2,57 sedangkan nilai $Z_{\text {tabel }}$ adalah 0,4949 maka Ha ditolak dan Ho diterima, artinya tidak terdapat perbedaan yang signifikan kemampuan berpikir kritis siswa pada materi sel antara kelas eksperimen dan kelas kontrol sebelum pembelajaran. Untuk lebih jelasnya dapat dilihat pada Tabel 6.

Tabel 6. Hasil Uji Hipotesis dengan Uji Z Dua Sampel untuk Pretest

\begin{tabular}{lccccc}
\hline \multicolumn{1}{c}{ Kelas } & N & $\begin{array}{c}\text { Rerata } \\
\text { Pretest }\end{array}$ & $\mathbf{z}_{\text {hitung }}$ & $\mathbf{Z}_{\text {tabel }}$ & Keterangan \\
\hline XI IPA 1 (Kelas Eksperimen) & 36 & 47 & $-2,57$ & 0,4949 & $\begin{array}{c}\text { Ha ditolak dan } \\
H_{0} \text { diterima }\end{array}$ \\
\hline XI IPA 2 (Kelas Kontrol) & 37 & 46,64 & $-2,6$ &
\end{tabular}

Berdasarkan hasil perhitungan hipotesis posttest kelas ekperimen dan kelas kontrol diketahui bahwa nilai $z_{\text {hitung }}$ adalah 30,33 sedangkan nilai $z_{\text {tabel }}$ adalah 0,4949 maka Ha diterima dan Ho ditolak, artinya terdapat perbedaan yang signifikan kemampuan berpikir kritis siswa pada materi sel antara kelas eksperimen dan kelas kontrol setelah pembelajaran. Untuk lebih jelasnya dapat dilihat pada Tabel 7.

Tabel 7.Hasil Uji Hipotesis dengan Uji Z Dua Sampel untuk Posttest

\begin{tabular}{cccccc}
\hline Kelas & $\mathbf{N}$ & $\begin{array}{c}\text { Rerata } \\
\text { Posttest }\end{array}$ & $\mathbf{Z}_{\text {hitung }}$ & $\mathbf{z}_{\text {tabel }}$ & Keterangan \\
\hline XI IPA (Kelas Eksperimen) & 36 & 87,41 & 30,33 & 0,4949 & $\begin{array}{c}\text { Ha diterima } \\
\text { dan } \mathrm{H}_{0} \text { ditolak }\end{array}$ \\
\hline
\end{tabular}




\section{PEMBAHASAN}

Sebelum sampel penelitian diberikan perlakuan, terlebih dahulu guru memberikan tes awal (pretest) kepada siswa kelas XI IPA 1 sebagai kelas eksperimen yang berjumlah 36 orang dan kelas XI IPA 2 sebagai kelas kontrol yang berjumlah 37 orang. Tes awal (pretest) diperoleh nilai rata-rata 47 untuk kelas eksperimen dan 46,64 untuk kelas kontrol. Analisis hasil pretest menunjukkan bahwa hanya 1 siswa di kelas eksperimen yang mencapai KKM dan 35 siswa yang tidak memenuhi kriteria ketuntasan minimal (KKM). Di kelas kontrol tidak terdapat siswa yang mencapai kriteria ketuntasan minimal (KKM).

Setelah diberikan perlakuan berbeda, untuk kelas eksperimen pembelajaran dilakukan dengan metode pembelajaran student facilitator and explaining berbantuan media peta timbul sedangkan kelas kontrol dengan pembelajaran konvensional, terjadi peningkatan nilai pada kedua kelas. Nilai rata-rata tes akhir (posttest) untuk kelas eksperimen yang diperoleh sebesar 87,41 terdapat 36 siswa atau $100 \%$ siswa yang memenuhi kriteria ketuntasan minimal (KKM). Rata-rata untuk kelas kontrol diperoleh 85,59 terdapat 37 siswa atau 100\% siswa yang memenuhi kriteria ketuntasan minimal (KKM).

Berdasarkan hasil tes tersebut, dapat disimpulkan bahwa rata-rata nilai tes akhir (posttest) kemampuan berpikir kritis siswa pada kelas eksperimen dengan rata-rata 87,41 lebih baik daripada rata-rata nilai tes akhir (posttest) kemampuan berpikir kritis siswa pada kelas kontrol dengan rata-rata 85,59. Hal ini sesuai dengan pendapat Suprijono (2009: 128) "Metode student facilitator and explainingmempunyai arti metode yang menjadikan siswa dapat membuat peta konsep maupun bagan untuk meningkatkan kreatifitas siswa dan prestasi siswa". Selanjutnya, siswa akan diajarkan bagaimana mereka mempelajari konsep dan bagaimana konsep tersebut dapatdipergunakan di luar kelas. Dengan penerapan metode student facilitator and explaning berbantuan media peta timbuldalam pembelajaran memungkinkan siswa untuk tahu manfaat darimateri yang dipelajari bagi kehidupannya, aktif dalam kegiatan pembelajaran, menemukan sendiri konsep-konsep yang dipelajari tanpa harus selalu tergantung pada guru, mampu memecahkan masalah-masalah yang berkaitan dengan konsep yang dipelajari, bekerja sama dengan siswa lain, dan berani untuk mengemukakan pendapat. Siswa menjadi lebih tertantang untuk belajar sehingga pengetahuan yang diperoleh akan lebih diingat oleh siswa.

Dengan demikian, peneliti menyimpulkan kemampuan berpikir kritis biologi siswa yang diajar dengan metode pembelajaran facilitator and explaning berbantuan media peta timbul akan lebih baik dibandingkan dengan siswa yang diajar dengan pembelajaran konvensional. Hal ini dilihat dari hasil uji hipotesis pretest kelas eksperimen dan kontrol dengan nilai $Z_{\text {hitung }}$ $2,57<Z_{\text {tabel }} 0,4949$. Sementara hasil uji hipotesis posttest kelas eksperimen dan kelas kontrol dengan nilai $Z_{\text {hitung }} 30,33<Z_{\text {tabel }} 0,4949$. Maka Ha diterima artinya terdapat perbedaan yang signifikan kemampuan berpikir kritis siswa pada materi sel antara kelas eksperimen dan kelas kontrol.

Hal menunjukkan adanya peningkatan kemampuan berpikir kritis dari hasil proses pembelajaran, namun peningkatan yang terjadi pada kelas eksperimen lebih tinggi jika dibandingkan dengan peningkatan yang terjadi pada kelas kontrol. Peningkatan tersebut dapat dilihat dari rata-rata nilai yang diperoleh kelas eksperimen dan kelas kontrol dari hasil perhitungan $\mathrm{N}$-gain kedua kelas yaitu $0,76<0,72$. Hasil ini didukung oleh penelitian sebelumnya Lia, (2015) "Rata-rata nilai hasil belajar Biologi siswa pada kelompok eksperimen yang belajar dengan model pembelajaran Student Facilitator and Explaining berbantuan media peta konsep lebih tinggi dari kelompok kontrol yang belajar secara konvensional yaitu 0,61 >0,41". Hasil penelitian ini juga didukung oleh keberhasilan penelitian Pawitra (2013) yang mengatakan "bahwa skor penguasaan konsep pada kelompok siswa setelah dibelajarkan dengan model pembelajaran student facilitator and explaining (SFAE) berbantuan media mind mapping berada pada kategori tinggi dengan rentangan 17,5 sampai dengan 22,5. Skor penguasaan konsep pada kelompok siswa setelah dibelajarkan dengan model pembelajaran konvensional berada pada Kategori sedang dengan rentangan 12,5 sampai dengan 17,5. 


\section{SIMPULAN}

Berdasarkan analisis dan pembahasan dalam penelitian ini secara umum dapat disimpulkan bahwa, terdapat perbedaan yang signifikan penggunaan metode student facilitator and explaining berbantuan media peta timbul terhadap kemampuan berpikir kritis siswa siswa pada materi sel kelas XI IPA Sekolah Menengah Atas Panca Setya Sintang tahun pelajaran 2016/2017". Hal ini ditunjukan pada hasil analisis uji hipotesis nilaipretestkelas ekperimen dan kontrol bahwa nilai $Z_{\text {hitung }}$ adalah $-2,57$ sedangkan nilai $z_{\text {tabel }}$ adalah 0,4949 . Hal ini berarti nilai $z_{\text {hitung }}<z_{\text {tabel }}$ yaitu $-2,57<0,4949$ maka Ho diterima yang artinya tidak terdapat perbedaan yang signifikan kemampuan berpikir kritis siswa pada materi sel antara kelas eksperimen dan kelas kontrol. Pada hasil analisis hipotesis nilaiposttest kelas eksperimen dan kelas kontrol bahwa nilai $Z_{\text {hitung }}$ adalah 30,33 sedangkan nilai $z_{\text {tabel }}$ adalah 0,4949 . Hal ini berarti nilai $z_{\text {hitung }}>z_{\text {tabel }}$ yaitu $30,33>0,4949$. Dengan peningkatan $\mathrm{N}$-gain sebesar $0,76<0,72$ maka Ha diterima yang artinya terdapat perbedaan yang signifikan kemampuan berpikir kritis siswa pada materi sel antara kelas eksperimen dan kelas kontrol.

\section{REFERENSI}

Fischer, A. (2008). Berpikir Kritis. Jakarta: Erlangga.

Lia, M. (2015). Penerapan Metode Student Facilitator And Explaining terhadap Penguasaan Konsep Siswa Di kelas X SMA Nusantara Indah Sintang pada Materi Keanekaragaman Hayati. Skripsi tidak diterbitkan. Sintang: Prodi Pendidikan Biologi STKIP Persada Khatulistiwa Sintang.

Pawitra, (2013). Pengaruh Model Pembelajaran Student Facilitator and Explaining Berbantuan Media Mind Mapping Terhadap Penguasaan Konsep IPA Siswa Kelas $\begin{array}{llllll}\text { IV } & \text { SDN } & 1 & \text { Sangsit. } & \text { (Online). } & \text { Tersedia: }\end{array}$ ejournal.undiksha.ac.id/index.php/JJPGSD/article/viewFile/738/611.pdf.

Sugiyono. (2013). Metode Penelitian Pendidikan. Bandung: Alfabeta.

Suprijono, A. (2009). Cooperative Learning Teori \& Aplikasi Paikem. Yogjakarta: Pustaka Pelajar.

Trianto. (2009). Mendesain Model Pembelajaran Inovatif-Progresif. Jakarta: Kencana Prenada Media Group.

Taniredja, T, dkk. (2013). Model-Model Pembelajaran Inovatif dan Efektif. Alfab 